\title{
Anatomy and Taxonomy of Three Species of Sea Anemones (Cnidaria: Anthozoa: Actiniidae) from the Gulf of California, Including Isoaulactinia bespervolita Daly, n. sp. ${ }^{1}$
}

\author{
Marymegan Daly ${ }^{2}$
}

\begin{abstract}
Specimens of actiniarians from the Gulf of California having a column densely covered with vesicles or verrucae have been attributed to one of three species: Anthopleura dowii, Bunodactis mexicana, or Bunodosoma californica. These three species are difficult to distinguish and are at least partly synonymous: Bunodosoma californica is a pro parte synonym of $A$. dowii and Bunodactis mexicana is a junior synonym of $A$. dowii. However, based on anatomy, coloration patterns, types of cnidae in the column, and habitat preferences, I discern three distinct species. I describe specimens attributed to Bunodactis mexicana not belonging to $A$. dowii as Isoaulactinia bespervolita, n. sp. I redescribe Bunodosoma californica and $A$. dowii and designate a lectotype for Bunodosoma californica to resolve taxonomic confusion.
\end{abstract}

Although members of the family Actiniidae are among the most common and best known sea anemones, distinguishing genera and species of actiniids is difficult because of the mosaic of traits that diagnose each genus (e.g., Carlgren 1921, 1949, Hand 1955, Dunn et al. 1980, England 1987, den Hartog 1987). Characters of primary importance in separating genera within Actiniidae, such as verrucae and acrorhagi (e.g., Carlgren, 1949) are indistinguishable based on external morphology from structures such as vesicles or pseudoacrorhagi (England 1987, den Hartog 1987, Riemann-Zürneck and Gallardo 1990). The ubiquity of actiniids also contributes to the problem of identification: many species belonging to Actiniidae may be found at a single locality.

${ }^{1}$ This work was supported by NSF DEB 9978106 (Partnerships in Enhancing Expertise in Taxonomy grant to D. G. Fautin). Manuscript accepted 18 June 2003.

2 Department of Ecology and Evolutionary Biology, University of Kansas, and Division of Invertebrate Zoology, University of Kansas Museum of Natural History and Biodiversity Research Center, Haworth Hall, 1200 Sunnyside Avenue, Lawrence, Kansas 66045 (phone, 785-864-4607; fax, 785-864-5321; e-mail, dalym@ku. edu).

Pacific Science (2004), vol. 58, no. 3:377-390

(C) 2004 by University of Hawai'i Press

All rights reserved
The actiniarian fauna of the Gulf of California includes three members of Actiniidae that are easily confused: Anthopleura dowii Verrill, 1869; Bunodactis mexicana Carlgren, 1951; and Bunodosoma californica Carlgren, 1951. Members of these species are similar in size and in tentacle number, and all have stout columns covered with hollow, vesicular outgrowths. An investigation of the type specimens of these three species illustrates how difficult they can be to distinguish: one of the three syntypes of Bunodosoma californica is a member of $A$. dowii, and both of the type specimens of Bunodactis mexicana are members of $A$. dowii. However, many specimens identified as Bunodactis mexicana are not members of $A$. dowii or of any other described actiniid; I describe them as Isoaulactinia bespervolita, n. sp. To differentiate clearly between these three species, I redescribe $A$. dowii and Bunodosoma californica, select a lectotype from among the syntypes of Bunodosoma californica, and provide differential diagnoses that use features visible in the field and after preservation.

\section{MATERIALS AND METHODS}

I examined live specimens in the field, freshly preserved material, and preserved museum specimens. I collected living specimens of $A$. dowii and I. bespervolita, n. sp., from the Gulf 

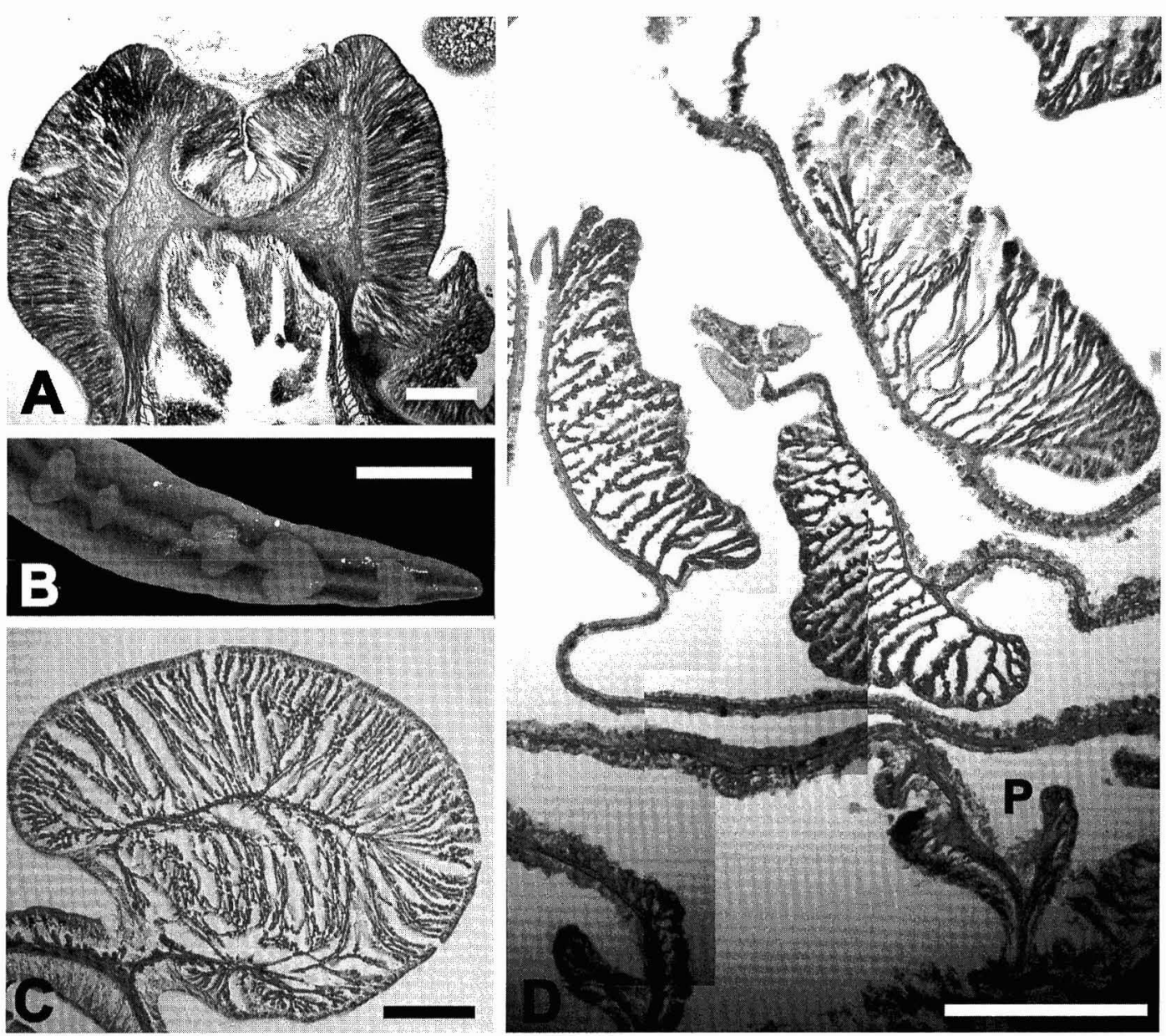

Figure 1. Histology of Anthopleura dowii Verrill, 1869. A. Section through a columnar verruca. Verruca fixed with shell debris attached; note mucus at apex, compare with Figure $2 A$. Scale $=50 \mu \mathrm{m}$. $B$. Oral surface of an inner tentacle, showing opaque markings typical of the species. Markings are visible in live and recently preserved specimens, but fade in ethanol over time. Scale $=5 \mathrm{~mm}$. $C$. Section through marginal sphincter. Scale $=50 \mu \mathrm{m}$. D. Cross section through mesenteries, proximal to the actinopharynx. Pennon of parietobasilar muscle (P) a broad flap, well differentiated from the mesenterial lamella. Parietobasilar and retractor muscles strong, restricted, with no visible muscle folds between them. Scale $=150 \mu \mathrm{m}$.

of California near La Paz, Baja California Sur, Mexico, and specimens of $A$. dowii and Bunodosoma californica from the Pacific Ocean near Todos Santos, Baja California Sur, Mexico. Specimens were allowed to expand, anesthetized in $3.5 \% \mathrm{MgSO}_{4}$, and fixed in $10 \%$ buffered seawater Formalin. All freshly collected specimens were transferred to $70 \%$ ethanol after approximately 2 weeks; these specimens have been deposited at the Uni- versity of Kansas Natural History Museum (кUNнм). Additional material was obtained through the California Academy of Sciences (CAS), U.S. National Museum of Natural History (USNM), and Yale University Peabody Museum (YPM).

Measurements of pedal disk width and column height were made on preserved material; for irregularly shaped specimens, greatest pedal disk width and greatest col- 

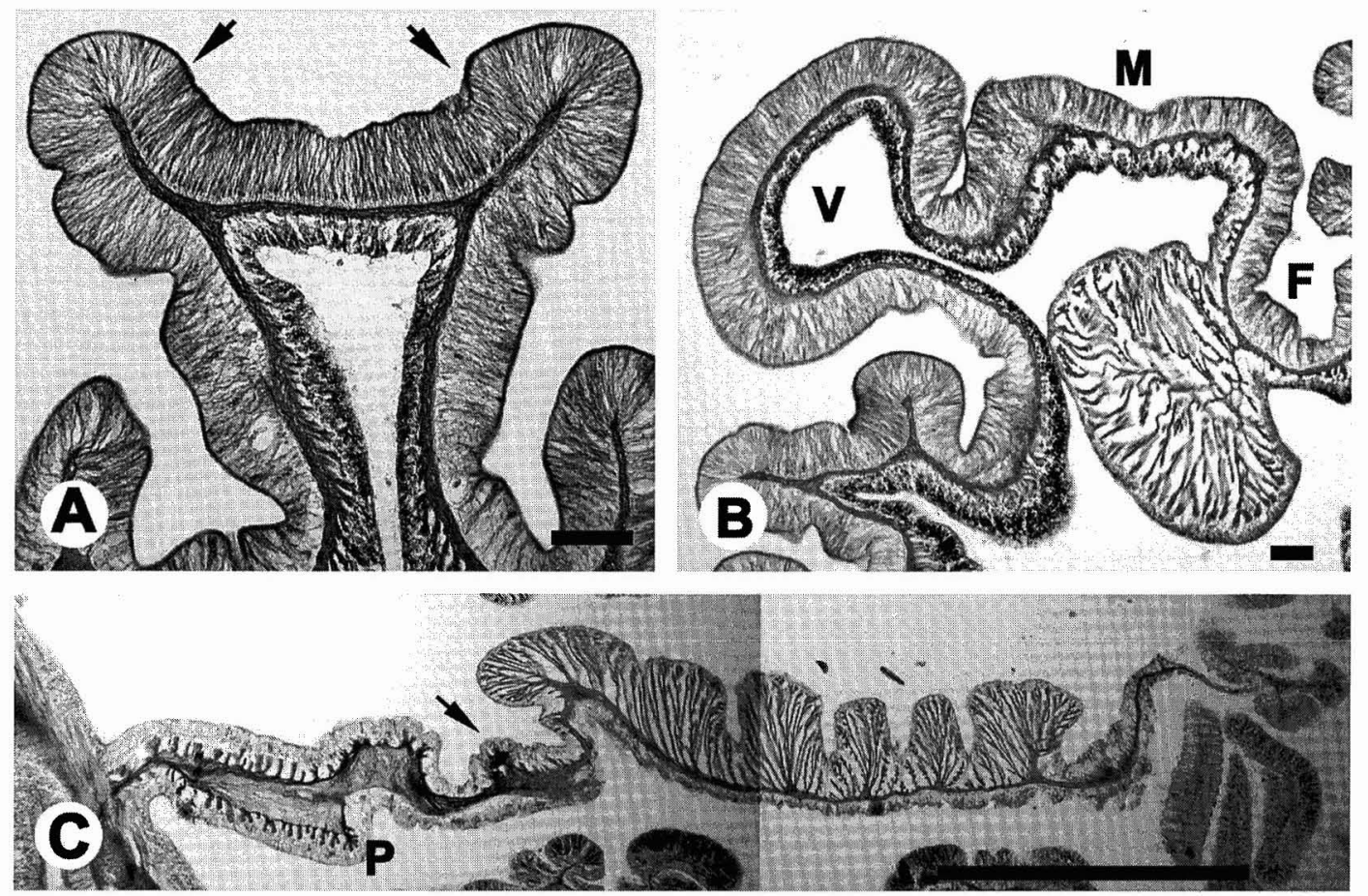

Figure 2. Histology of Isoaulactinia bespervolita, n. sp. $A$. Section through a columnar verruca. Area between arrows indicates specialized region: note bilayered appearance of ectoderm near the junction with the mesoglea, and thin, densely packed epitheliomuscular cells in the ectoderm. Compare with Figures $1 A, 3 A$. Scale $=50 \mu \mathrm{m}$. $B$. Section through margin showing sphincter. At the margin $(M)$, each endocoel and exocoel terminates in a single verruca (V) that does not contain holotrichs. Because the margin is flat rather than denticulate, the fosse $(\mathrm{F})$ is shallower than in $A$. dowii or Bunodosoma californica. Scale $=50 \mu \mathrm{m}$. C. Cross section through mesenteries, proximal to the actinopharynx. Pennon of the parietobasilar muscle $(\mathrm{P})$ is not very broad. Note accessory muscles (arrow) between parietobasilar and retractor muscles. Scale $=500 \mu \mathrm{m}$.

umn height were recorded. Longitudinal and transverse serial sections $6-10 \mu \mathrm{m}$ thick were made from specimens dehydrated in ethanol and embedded in Paraplast. Sections were stained in Heidenhain's Azan (Presnell and Schreibman 1997).

Small pieces (approximately $1 \mathrm{~mm}^{2}$ ) of tentacle, column, marginal spherule, limbus, actinopharynx, and mesenterial filament tissue were squashed on a slide and examined at $1,000 \times$ using differential interference microscopy; length and width of undischarged cnidae were measured using ScanPro measurement software (Jandel Scientific Software 1995) and a Summa Sketch digitizing tablet (Summagraphics). For each species, cnidae were measured from specimens represent- ing the geographic and size variation of the specimens examined. For each tissue sample, I searched for the largest and smallest cnidae of a particular type (Hand 1955, England 1987). Nomenclature of cnidae follows Mariscal (1974).

\section{Verrucae and Vesicles}

This trio of species provides an excellent opportunity to explore the differences between columnar vesicles and verrucae. The primary distinction between the genus $A n$ thopleura and the genus Bunodosoma is based on the nature of the hollow columnar outgrowths: in Anthopleura, these structures are cup-shaped, adhesive, and are called verrucae; 


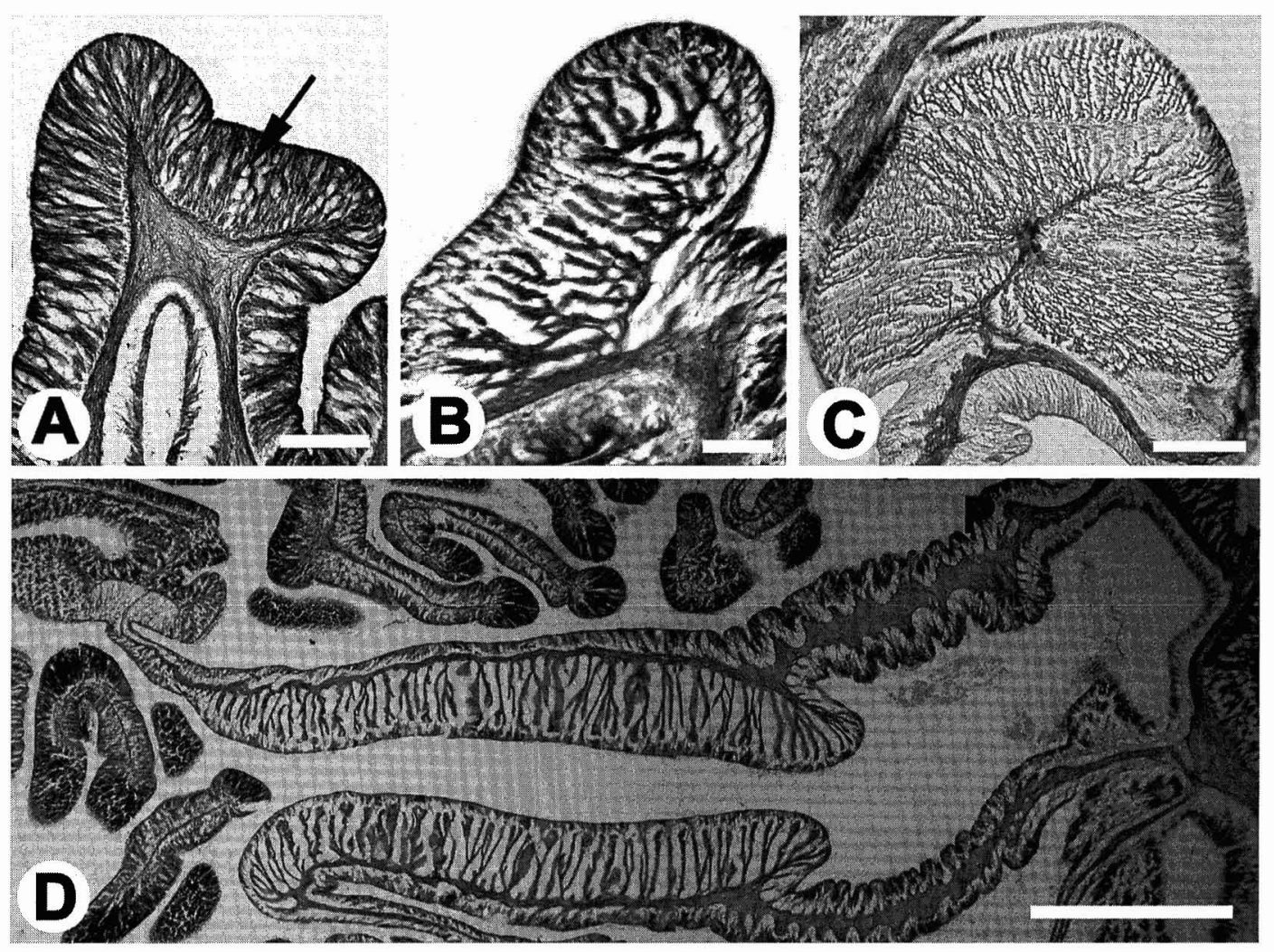

Figure 3. Histology of Bunodosoma californica Carlgren, 1951. A. Section through a columnar vesicle. Note thickness of mesoglea at apex, mucous gland cells (arrow), and similarity of ectoderm on apex and sides of vesicle; compare with Figures $1 A, 2 A$. Scale $=50 \mu \mathrm{m}$. B. Section through marginal sphincter (кunнm 1619). Scale $=50 \mu \mathrm{m}$. C. Section through the marginal sphincter muscle of a highly contracted specimen (cAs 95945); compare with Figure $3 B$. Scale $=100 \mu \mathrm{m}$. D. Section through mesenteries proximal to the actinopharynx. Parietobasilar muscle weak, with very small pennon $(\mathrm{P})$. Scale $=150 \mu \mathrm{m}$.

in Bunodosoma, the structures are rounded, typically nonadhesive, and are called vesicles. Isoaulactinia is also characterized as having cup-shaped, adhesive verrucae. Distinguishing between verrucae and vesicles is not trivial in practice, especially when dealing with preserved specimens: verrucae may drop their attached shells and debris during preservation or collection, and rounded vesicles may become deflated and resemble verrucae.

Verrucae are well defined anatomically: a verruca is an adhesive, hollow evagination of all three layers of the column wall, with thick, glandular ectoderm that lacks nematocysts, relatively thin mesoglea (especially at the center, where it may form a cinclis), and relatively thin, unmuscular endoderm (Figures $1 A, 2 A$ ) (Stephenson 1928, den Hartog 1987, Riemann-Zürneck and Gallardo 1990). The columnar evaginations of members of Bunodosoma are typically nonadhesive or only weakly adhesive (e.g., Verrill 1899, Stephenson 1918, 1928, Carlgren 1921, 1928, 1938, den Hartog 1987) and may or may not have nematocysts (e.g., Carlgren 1921, 1928, 1938, den Hartog 1987).

Because of its variability among species of Bunodosoma, the morphology of a vesicle needs to be described in more detail than that of a verruca. In Bunodosoma californica (Figure $3 A$ ), the vesicles are nonadhesive: I observed no material adhering to them in the field nor 
do any of the museum specimens I examined have foreign matter attached to them. I found no cnidae in the ectoderm at the apex of the vesicles in any of the sections I examined. Although the cross-sectional shape of a vesicle in specimens of Bunodosoma californica may closely resemble that of a verruca (e.g., Figures $2 A, 3 A$ ), the histology differs. A verruca is typically cup-shaped; a vesicle on the column of a specimen of Bunodosoma californica never appears cup-shaped, even when the underlying mesoglea takes a shape resembling that of a verruca. The mesoglea of a verruca is thinner at the apex than at the sides (Figures $1 A, 2 A$ ); the opposite is true of a vesicle of a member of Bunodosoma californica (Figure 3A). In Bunodosoma californica, the apex of a vesicle contains globular mucous gland cells (Figure $3 A$ ), unlike the apex of a verruca. The ectoderm at the apex of a vesicle is not differentiated from the ectoderm of the sides of the vesicle (Figure 3A): the ectoderm is of a similar thickness and contains similar cells. In a verruca (e.g., Figures $1 A, 2 A$ ), the cells in the ectoderm of the apex are thinner than those at the sides and are typically thinner at the base (adjacent to the mesoglea), so that the ectoderm appears stratified (Figures $1 \mathrm{~A}$, 2A).

The seemingly generic term "vesicle" refers specifically to hollow evaginations of the column with nematocyst batteries in members of Boloceroidaria (e.g., Stephenson 1928, Carlgren 1949). Carlgren (1928, 1938) reported that the columnar outgrowths of $\mathrm{Bu}$ nodosoma capensis formed "weak nematocyst batteries" and considered this a characteristic of the genus. In contrast, den Hartog (1987) found no cnidae in the columnar outgrowths of Bunodosoma biscayensis (Fischer, 1874) and so objected to the use of the term "vesicle" for the columnar evaginations of Bunodosoma biscayensis. Although Verrill (1899) explicitly distinguished between the nonadhesive "vesicles" of the column of Bunodosoma and the adhesive "suckers" characteristic of Antbopleura or Bunodactis in his description of Bunodosoma, den Hartog (1987) suggested that the two are identical, varying only in the degree of adhesiveness. The adhesiveness of structures unequivocally considered verrucae varies: in live specimens of Anthopleura xanthogrammica (Brandt, 1835), the verrucae are much less adhesive than in specimens of $\mathrm{An}$ thopleura elegantissima (Brandt, 1835) found in the same location (Hand 1955; pers. obs.). However, in at least some taxa, such as Bunodosoma californica, vesicles differ in both anatomy and function from verrucae. The "vesicles" of members of Bunodosoma are variable with respect to the criteria used to characterize columnar structures, suggesting that a more comprehensive anatomical and taxonomic revision is needed.

\section{SYSTEMATIC ACCOUNT}

Anthopleura dowii Verrill, 1869

Figures $1,4 A, 5 A-C, K-M, 6,8 A$

Anthopleura Dowii Verrill, 1869; Verrill 1899:44.

Anthopleura Dovi Verr. Andres 1883.

Anthopleura dowii Carlgren 1949, 1951; Geller and Walton 2001.

Anthopleura sp. 1 Francis 1988.

Bunodactis mexicana Carlgren 1949, 1951.

DIAGNOSIS: Actiniidae with brownish green column covered from margin to limbus with rows of endocoelic adhesive verrucae. Margin with endocoelic verrucae atop marginal projections; each projection bears a single holotrichous acrorhagus on its oral surface. Holotrichs of acrorhagi dimorphic. Oral disk with rays of pink, purple, or orange extending from tentacles to mouth. Tentacles may be pink, orange, or purple, each typically bearing an opaque white longitudinal stripe and white crossbars. Tentacles arranged in three or four cycles, approximately 60 total. Patterning of the oral disk and tentacles distinguishes $A$. dowii from $I$. bespervolita, n. sp., in the field; the morphology of the margin and of the columnar holotrichs distinguishes preserved specimens of these two species. The cup-shaped, endocoelic verrucae distinguish living members of $A$. dowii and $B u$ nodosoma californica; the holotrichs of the acrorhagi and the cnidom of the column distinguish preserved members of $A$. dowii from 

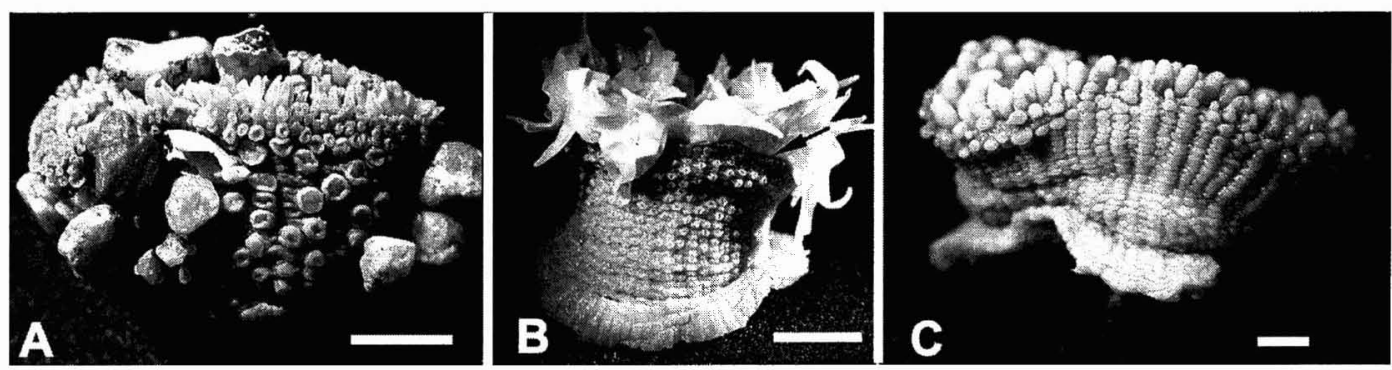

Figure 4. External appearance of Anthopleura dowii, Isoaulactinia bespervolita, and Bunodosoma californica. Scale $=5 \mathrm{~mm}$. A. Specimen of Anthopleura dowii (кUNнм 1617). Note collar of verrucae at margin; large, cup-shaped verrucae on column; and relatively short, conical tentacles. B. Holotype of Isoaulactinia bespervolita, n. sp. (кuNHM 1790). Note small, cup-shaped verrucae in lines on column and long, conical tentacles. Margin smooth (arrow). C. Specimen of Bunodosoma californica (кUNHм 1619). Note densely packed, rounded vesicles and short, blunt tentacles.

those of Bunodosoma californica. Anthopleura artemisia (Pickering in Dana, 1846), a species common in central and southern California, resembles $A$. dowii in coloration and habitat but differs in the size of the cnidae and in having verrucae only on the distal column (see Hand 1955).

COLUMN: Freshly collected specimens olive green to brown; verrucae lighter in color, pale green to gray. Column diameter varies greatly among specimens: width of live specimens $10-35 \mathrm{~mm}$, preserved specimens, $8-27 \mathrm{~mm}$. Height not measured in the field because animals typically live with the column in sand; preserved specimens $10-31 \mathrm{~mm}$ tall. Adherent base roughly circular in outline, same color as column, with strong basilar muscles. Column of uniform diameter or slightly wider distally. Fosse deep. Margin denticulate, with endocoelic marginal projections each bearing three or four verrucae on the adoral surface and a single opaque white acrorhagus on the oral surface. Verrucae of column endocoelic, more prominent distally, in rows to limbus (Figures $4 A, 6,8 A$ ). In contracted specimens, verrucae and marginal projections may form a dense "collar" proximal to the tentacle crown (Figures $4 A, 6$ ). Verrucae approximately same size distally and proximally; maximum diameter of verrucae less than $0.75 \mathrm{~mm}$ in preserved specimens. Space between verrucae greater in larger specimens. In life, verrucae hold small stones and pieces of shells.
TENTACLES AND ORAL DISK: Oral disk green to brownish purple, with white and/or pinkish orange lines radiating from mouth. Markings on oral disk may be blotchy, with lines indistinct so that large portions of oral disk are white, pink, or orange. Mouth reddish or green, atop oral cone. Tentacles dark purple to orange pink, slender, conical, perforate, in three to four cycles, approximately $10-15 \mathrm{~mm}$ long in expanded preserved individual; typically equal in length to the diameter of oral disk in life. Innermost tentacles typically longer and darker than outermost tentacles. Oral surface of tentacle typically bears several opaque white cross-marks and a single opaque white longitudinal line (Figure $1 B)$. Adoral surface of tentacle may have a single dark longitudinal stripe.

MESENTERIES AND INTERNAL ANATOMY: Two aborally prolonged siphonoglyphs typically attached to directive mesenteries. All larger mesenteries have large oral and marginal stoma; marginal stoma of largest mesenteries exceptionally large. Mesenteries in three to five cycles, same number distally and proximally; hexamerous arrangement may be obscured by regeneration after longitudinal fission. Mesenteries of first three or four cycles typically perfect; all perfect mesenteries, including directives, fertile. Imperfect mesenteries sterile. Gonochoric. Mesenterial retractor muscles strong, restricted (Figure 1D). Parietobasilar muscles strong, with narrow, long pennon (Figure 1D). Marginal sphincter 
strong, circumscribed, pinnate, pedunculate (Figure $1 C$ ).

CNIDOM: Spirocysts, basitrichs, microbasic $b$-mastigophores, microbasic $p$-mastigophores, holotrichs (Figure $5 A-C, K-M$ ). Sizes and distribution of cnidae given in Table 1.

DISTRIBUTION AND NATURAL HISTORY: Pacific Ocean and Gulf of California, Baja California Sur, Mexico, to Panama. Intertidal, on boulders, in areas of high wave action and in tide pools buried in sand up to oral disk. Undergoes longitudinal fission.

TYPE MATERIAL: Syntypes: Collected by F. H. Bradley, 1866, West Coast [Pacific Ocean], Panama (YPM 2102); collected by F. H. Bradley, 1866, [Pacific Ocean], El Salvador, Acajutla; collected by F. H. Bradley, 1866, [Pacific Ocean], Nicaragua, El Realejo (YPM 2104).

OTHER MATERIAL EXAMINED: Collected by $M$. Daly and L. Francis, 13 November 2001, intertidal, Pacific Ocean, Mexico, Baja California Sur, Los Cerritos (кUNнm 1614, 1617); collected by M. Daly and L. Francis, 11 November 2001, intertidal, Gulf of California, Mexico, Baja California Sur, Tecolote (кUNнм 1615, 1616); collected by E. F. Ricketts, 30 March 1940, Gulf of California, Mexico, Sonora, San Carlos Bay (Usnm 49451); collected by E. F. Ricketts, 26 March 1940, Gulf of California, Mexico, [Baja California Sur], Puerto Escondido (USNM 49396); collected by S. F. Hildebrandt, 26 March 1937, Panama Canal, Panama, Miraflores Locks (USNM 52357).

TAXONOMIC REMARKs: The type specimens of Bunodactis mexicana lack exocoelic verrucae at the margin, having instead distinct endocoelic marginal projections, each of which bears several verrucae on the adoral surface and a single holotrichous acrorhagus on the oral surface (Figure 6). The cnidae of these specimens are identical to those of the specimens of $A$. dowii I examined; furthermore, the cnidom lacks the macrobasic $p$ mastigophores and large columnar holotrichs characteristic of specimens described here as I. bespervolita, n. sp. The strongly pinnate sphincter muscle figured by Carlgren (1951: fig. 79a) as representative of Bunodactis mex-

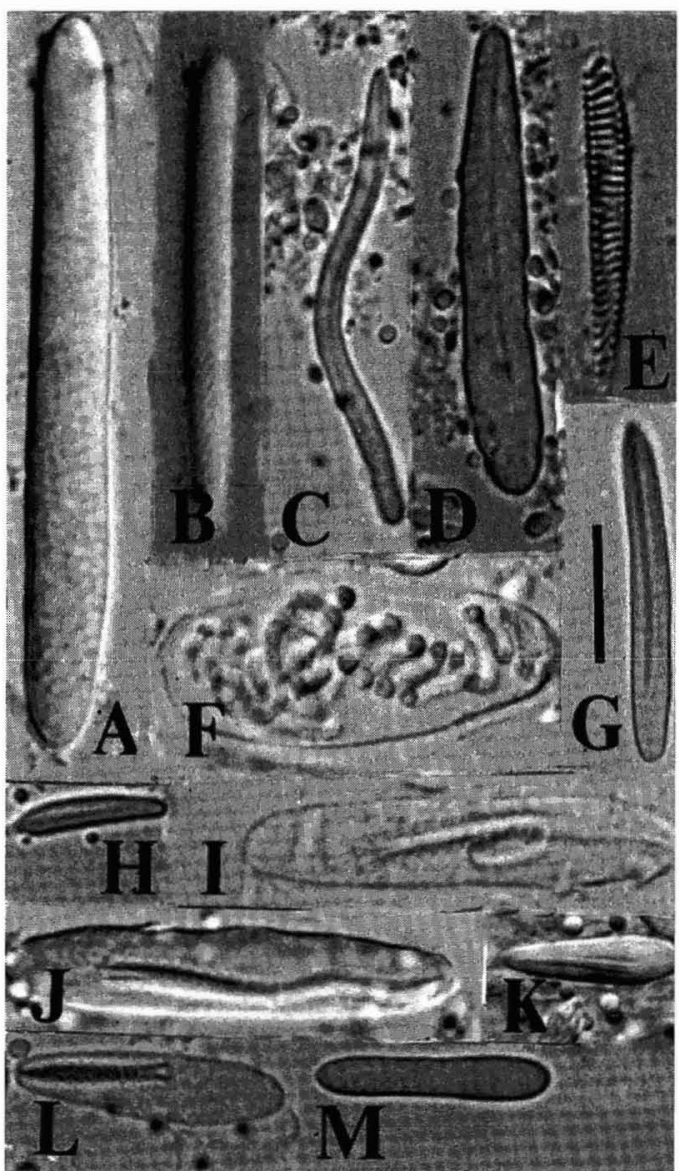

Figure 5. Cnidae of Isoaulactinia bespervolita, Anthopleura dowii, and Bunodosoma californica. The species that is the source of each illustrated cnida is given after the name of each type; because the morphology of each type of cnida was similar for all three species, only a single example of each type is shown. Refer to Tables 1-3 for distribution and specific size information. Scale $=10 \mu \mathrm{m}$. A. Wide holotrich, $A$. dowii. B. Thin holotrich, $A$. dowii. $C$. S-shaped basitrich, $A$. dowii. $D$. Large microbasic $b$ mastigophore, Bunodosoma californica. E. Spirocyst, I. bespervolita. F. Spinose holotrich, I. bespervolita. G. Large basitrich, I. bespervolita. H. Small basitrich, Bunodosoma californica. I. Macrobasic p-mastigophore, I. bespervolita. 7. Microbasic p-mastigophore II, I. bespervolita. $K$. Microbasic $b$-mastigophore, $A$. dowii. L. Microbasic $p$ mastigophore I, A. dowii. M. Small holotrich, A. dowii.

icana resembles the sphincter muscles illustrated for $A$. dowii in the same publication (i.e., Carlgren 1951: figs. 78e,f); the cnidae Carlgren (1951) reported for Bunodactis mexicana are more similar to those of $A$. dowii 
TABLE 1

Cnidae of Anthopleura dowii

\begin{tabular}{|c|c|c|c|c|c|}
\hline Tissue & Cnida & $\mathrm{N}$ & $n$ & Range $(\mu \mathrm{m})$ & $\begin{array}{l}\text { Range given in } \\
\text { Carlgren (1951) }\end{array}$ \\
\hline \multirow{3}{*}{ Tentacle } & Spirocyst (E) & $5 / 5$ & 216 & $11.0-28.2$ by $1.4-3.8$ & \\
\hline & Small basitrich $(\mathrm{H})$ & $5 / 5$ & 59 & $8.0-13.2$ by $1.7-2.9(3.3)$ & \\
\hline & Large basitrich $(\mathrm{G})$ & $5 / 5$ & 221 & $13.3-28.1$ by $1.6-3.9$ & $15.5-22.6$ by $2.2-2$. \\
\hline \multirow[t]{4}{*}{ Acrorhagus } & Small basitrich $(\mathrm{H})$ & $5 / 5$ & 31 & $5.9-14.0$ by $1.2-3.1$ & \\
\hline & Large basitrich (G) & $5 / 5$ & 28 & $17.2-21.5$ by $2.1-3.4$ & \\
\hline & Thin holotrich (B) & $5 / 5$ & 113 & $32.2-62.5$ by $(2.2) 2.4-5.0$ & \\
\hline & Wide holotrich (A) & $5 / 5$ & 119 & $32.9-58.4$ by $4.5-8.4$ & \\
\hline \multirow[t]{2}{*}{ Distal column } & Small basitrich $(\mathrm{H})$ & $5 / 5$ & 83 & $8.2-14.8$ by $1.4-2.8$ & \\
\hline & Large basitrich (G) & $5 / 5$ & 85 & $12.4-26.5$ by $1.8-3.6$ & $14-18.3$ by $2.5-2.8$ \\
\hline \multirow[t]{3}{*}{ Limbus } & Small basitrich $(\mathrm{H})$ & $4 / 5$ & 27 & $8.7-15.9$ by $1.4-3.1$ & \\
\hline & Large basitrich (G) & $5 / 5$ & 93 & $\begin{array}{l}\text { (12.4) } 14.0-28.8 \text { by (1.6) } \\
2.2-4.5\end{array}$ & \\
\hline & Small holotrich (M) & $5 / 5$ & 78 & $14.3-29.7$ by (2.4) $3-5.9$ & \\
\hline \multirow{3}{*}{ Actinopharynx } & Small basitrich $(\mathrm{H})$ & $5 / 5$ & 131 & $10.2-16.9$ by $1.4-3.1$ & \\
\hline & Large basitrich (G) & $5 / 5$ & 160 & $17.7-29.5$ by $2.4-4.3$ & $21-28$ by 3 \\
\hline & $\begin{array}{l}\text { Microbasic } \\
\quad p \text {-mastigophore I (L) }\end{array}$ & $4 / 5$ & 115 & $13.7-24.0$ by $3.4-6.6$ & $19-22.6$ by $4.5-5$ \\
\hline \multirow[t]{5}{*}{ Filament } & Small basitrich $(\mathrm{H})$ & $5 / 5$ & 61 & $11.1-21.2$ by $1.6-3.3$ & $11.3-16.2$ by 2.8 \\
\hline & $\begin{array}{l}\text { Large microbasic } \\
\quad b \text {-mastigophore (D) }\end{array}$ & $5 / 5$ & 73 & $24.7-46.5$ by $3-6.4(7.8)$ & $19-33.8$ by $5.6-6.3$ \\
\hline & $\begin{array}{l}\text { Microbasic } \\
\quad b \text {-mastigophore (K) }\end{array}$ & $5 / 5$ & 44 & $\begin{array}{l}15.1-23.0 \text { by }(2.2) \\
2.8-5.0(5.6)\end{array}$ & \\
\hline & $\begin{array}{l}\text { Microbasic } \\
\quad \text { p-mastigophore I (L) }\end{array}$ & $5 / 5$ & 111 & (12.8) $14.5-26.4$ by $2.8-5.7$ & $21-24$ by $4.2-5$ \\
\hline & S-shaped basitrich (C) & $4 / 5$ & 36 & $25-36.9$ by $1.2-2.5$ & \\
\hline
\end{tabular}

Note: $\mathrm{N}$ is the proportion of examined individuals having a particular type of cnida; $n$ is the number of capsules measured. Values in parentheses are measurements from exceptionally small or large cnidae. Letters refer to Figure 5. Although the size ranges for "large" and "small" basitrichs overlap in the aggregate, in any one specimen the ranges do not overlap. The size ranges reported by Carlgren (1951) for the cnidae of B. mexicana are within the range of those observed here.

than to those of $I$. hespervolita, n. sp. (see Tables 1, 2).

Isoaulactinia bespervolita Daly, n. sp.

Figures 2, 4B, $5 E-G, I-7$

Bunodactis mexicana Brusca 1973; Kerstitch 1989.

non Bunodactis mexicana Carlgren: Carlgren

1949, nomen nudum; Carlgren, 1951.

Differential Diagnosis: Actiniidae with orange to brown column covered from margin to limbus with rows of endocoelic adhesive verrucae. Oral disk and tentacles same color as column, unmarked. Margin with endocoelic and exocoelic verrucae but without holotrichous acrorhagi. Tentacles arranged in four or five cycles, approximately 80 total. Tentacles and column contain macrobasic $p$-mastigophores. Unmarked tentacles and oral disk distinguish $I$. bespervolita from A. dowii and Bunodosoma californica in the field; macrobasic $p$-mastigophores and morphology of margin distinguish $I$. hespervolita from A. dowii and Bunodosoma californica after preservation. Isoaulactinia bespervolita differs from Isoaulactinia stelloides (McMurrich 1889), the only other described species of Isoaulactinia, in having an unmarked oral disk and tentacles, in being gonochoric rather than hermaphroditic, and in having holotrichs in the column.

CoLUMN: Freshly collected specimens reddish orange to greenish brown; verrucae same color as column. Width of column ap- 


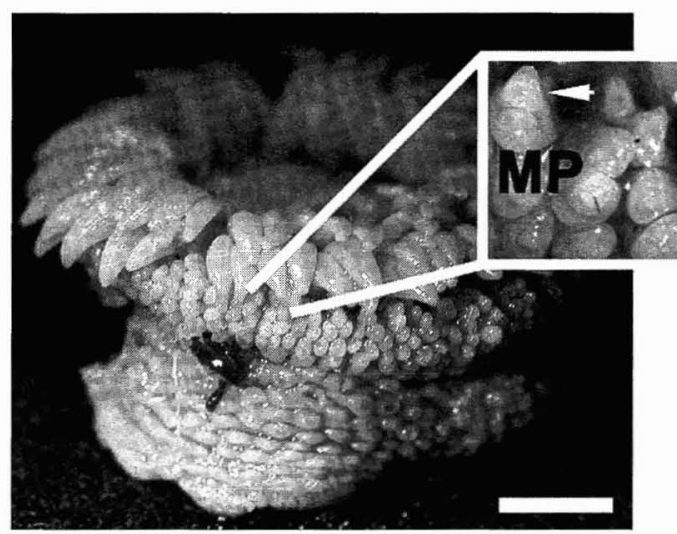

FIgURE 6. Syntype of Bunodactis mexicana Carlgren, 1951 (USNM 49451). This specimen belongs to Anthopleura dowii: it has a collar of verrucae and marginal projections (MP, inset) that each bear an acrorhagus on the oral surface (arrow, inset). Compare with Figure 4A,B. Scale $=5 \mathrm{~mm}$.

proximately $10-30 \mathrm{~mm}$, height approximately 10-35 mm (expanded live specimens); width of preserved holotype $28 \mathrm{~mm}$, height $17 \mathrm{~mm}$. Adherent base roughly circular in outline, same color as distal column, with strong basilar muscles. Column typically of uniform diameter. Fosse (Figure 2B) shallow in contracted preserved specimens. Distalmost verrucae endocoelic and exocoelic: exocoelic verrucae number two or three per coelenteric space, present only near margin; endocoelic verrucae in regular vertical rows to limbus (Figure 4B). Verrucae approximately same size distally and proximally; maximum diameter less than $1.0 \mathrm{~mm}$ in preserved specimens (Figure 2A). In life, verrucae hold small stones and pieces of shells; material typically is dropped when specimen is disturbed.

ORAL DISK AND TENTACles: Oral disk and tentacles same color as column, without markings. Oral disk diameter of expanded individuals equal to or slightly greater than pedal disk diameter. Mouth atop oral cone, elongate along directive axis. Tentacles slender, conical, with slightly rounded tip, studded with small batteries of nematocysts, number 72-96 (85 in holotype), in three to four cycles, approximately $10 \mathrm{~mm}$ long in expanded preserved individual, innermost

\section{TABLE 2}

Cnidae of Isoaulactinia berpervolita

\begin{tabular}{|c|c|c|c|c|}
\hline Tissue & Cnida & $\mathrm{N}$ & $n$ & Range $(\mu \mathrm{m})$ \\
\hline \multirow[t]{3}{*}{ Tentacle } & Spirocyst (E) & $6 / 6$ & 112 & $9.9-23.8$ by $1.5-2.8$ \\
\hline & Small basitrich $(\mathrm{H})$ & $6 / 6$ & 97 & (12.6) $13.7-24.2$ by $1.8-3.6$ \\
\hline & Large basitrich (G) & $6 / 6$ & 109 & $18.0-31.2$ by $2.1-3.6$ \\
\hline \multirow[t]{2}{*}{ Distal column } & Small basitrich $(\mathrm{H})$ & $6 / 6$ & 86 & $11.7-17.9$ by $1.4-2.9$ \\
\hline & Microbasic $p$-mastigophore I (L) & $6 / 6$ & 69 & $23.0-30.0$ by $4.4-6.9$ \\
\hline \multirow[t]{6}{*}{ Column } & Small basitrich $(\mathrm{H})$ & $6 / 8$ & 65 & $7.3-12.2$ by $1.2-2.8$ \\
\hline & Large basitrich (G) & $8 / 8$ & 185 & $13.5-22.6$ by $1.7-3.0(3.8)$ \\
\hline & S-basitrich $(\mathrm{C})$ & $7 / 8$ & 52 & $18.3-48.9$ by $1.2-2.4$ \\
\hline & Microbasic $p$-mastigophore II $(\mathrm{J})$ & $7 / 8$ & 86 & $25.0-44.1$ by $4.8-9.4$ \\
\hline & Macrobasic $p$-mastigophore (I) & $6 / 8$ & 44 & $26.5-39.4$ by $6.2-9.1$ \\
\hline & Spinose holotrich $(\mathrm{F})$ & $7 / 8$ & 55 & $20.1-45.0$ by $9.9-17.5$ \\
\hline \multirow[t]{3}{*}{ Actinopharynx } & Small basitrich (E) & $4 / 5$ & 65 & $10.9-22.2(23.8)$ by $1.8-3.4(3.6)$ \\
\hline & Large basitrich $(\mathrm{G})$ & $5 / 5$ & 68 & $22.0-33.4$ by $2.3-4.3$ \\
\hline & Microbasic $p$-mastigophore I (L) & $5 / 5$ & 56 & $18.7-34.2$ by (3.4) $3.7-6.8(7.8)$ \\
\hline \multirow[t]{5}{*}{ Filament } & Small basitrich $(\mathrm{H})$ & $4 / 4$ & 55 & $12.0-21.2$ by $(0.8) 1.3-3.0$ \\
\hline & Large basitrich $(\mathrm{G})$ & $3 / 4$ & 13 & $24.4-29.4$ by (2.0) $3.2-5.3$ \\
\hline & Microbasic $b$-mastigophore (K) & $4 / 4$ & 52 & $33.8-48.8$ by $4.2-6.9$ \\
\hline & Microbasic $p$-mastigophore I (L) & $4 / 4$ & 46 & $16.5-27.2$ by $3.6-7.8$ \\
\hline & Microbasic $p$-mastigophore II $(\mathrm{J})$ & $4 / 4$ & 67 & $30.1-46.7$ by $5.1-10.1(12.7)$ \\
\hline
\end{tabular}

Note: $\mathrm{N}$ is the proportion of examined individuals having a particular type of cnida; $n$ is the number of capsules measured. Values in parentheses are measurements from exceptionally small or large cnidae. Letters refer to Figure 5. Although the size ranges for "large" and "small" basitrichs overlap in the aggregate, in any one specimen the ranges do not overlap. More samples were examined from the column than from other tissues to confirm that the spinose holotrichs were not contaminants. Microbasic $p$-mastigophores II may be immature macrobasic $p$-mastigophores. 
tentacles slightly longer than outermost tentacles. Zooxanthellae numerous in endoderm of tentacles.

MESENTERIES AND INTERNAL ANATOMY: Two siphonoglyphs attached to directive mesenteries. Perfect mesenteries with oral and marginal stoma; oral stoma of largest mesenteries larger than marginal stoma. Mesenteries in four or five cycles, same number distally and proximally, arranged hexamerously. Mesenteries of first three cycles typically perfect; all perfect mesenteries except directives fertile. Imperfect mesenteries sterile. Gonochoric. Mesenterial retractor muscles diffuse, lobed, with accessory muscles (Figure 2C). Parietobasilar muscles with many short lateral branches and short flap (= pennon) (Figure 2C). Marginal sphincter strong, circumscribed, palmate (Figure $2 B$ ). Zooxanthellae sparse in endoderm of column and mesenteries.

сліDом: Spirocysts, basitrichs, microbasic $b$-mastigophores, microbasic $p$ mastigophores, macrobasic $p$-mastigophores, holotrichs (Figure $5 E-G, I-\mathcal{Z}$ ). Sizes and distribution given in Table 2.

DISTRIBUTION AND NATURAL HISTORY: Pacific Ocean and Gulf of California, Baja California Sur, Mexico. Intertidal, attached to rocks with column sometimes buried in sand; more common than either $A$. dowii or Bunodosoma californica in embayments, less common than either $A$. dowii or Bunodosoma californica in exposed rocky habitats. Ability to undergo fission unknown; no specimens with fission scars or anatomical irregularities.

ETyMology: The specific epithet bespervolita is a Latin translation of Western Flyer, the vessel used by Ed Ricketts, John Steinbeck, and crew during their "Sea of Cortez" expedition (Steinbeck 1951). Bunodactis mexicana was originally described from specimens collected during that expedition, and the Log from the Sea of Cortez (Steinbeck 1951) mentions unidentified "bunodid" anemones that may be $I$. bespervolita.

TyPe material: Holotype: Collected by M. Daly and L. Francis, 11 November 2001, intertidal, Gulf of California, Mexico, Baja California Sur, La Paz (киnнм 1790). Paratypes: Collected by M. Daly and L. Francis, 11 November 2001, intertidal, Gulf of Cali- fornia, Mexico, Baja California Sur, La Paz (кUNHM 1618); collector unknown, 30 June 1984, intertidal, Pacific Ocean, Mexico, Baja California Sur, Bahía Sebastian Vizcaino (cAs 50146).

OTHER MATERIAL EXAMINED: Collector unknown, 30 June 1984, intertidal, Pacific Ocean, Mexico, Baja California Sur, Bahía Sebastian Vizcaino (CAS 052680); collector unknown, 3 July 1984, Gulf of California, Mexico, Baja California Sur, Punta Abreojos (cas 50138); collected by P. E. Pickens, 25 July 1964, Gulf of California, Sonora, Puerto Penasco.

TAXONOMIC REMARKs: This species has macrobasic $p$-mastigophores (= $p$-mastigophores A2 of Belém et al. 1996), the same number of mesenteries proximally and distally, and linearly arranged verrucae; it is therefore a member of Isoaulactina Belém, Herrera \& Schlenz, 1996. The cnidom of this species is unlike that of Aulactinia Verrill, 1864, because it includes macrobasic $p$-mastigophores; the cnidom and the morphology of the margin in this species are unlike those of Gyractis Boveri, 1893 (see England 1987). The holotrichs in the column are not like those England (1987) considered characteristic of Anthopleura Duchassaing \& Michelotti, 1860 (compare Figure 5A,B,F), nor does this species have the holotrichous acrorhagi characteristic of Antbopleura (see Hand 1955, England 1987, Belém and Pinto 1990, Daly and den Hartog in press).

\section{Bunodosoma californica Carlgren, 1951}

Figures $3,4 C, 5 D, H, 7,8$

\section{Bunodosoma californica Carlgren 1949 nomen nudum; Carlgren 1951; Carlgren: McCommas 1983, 1991.}

DIAGNosis: Actiniidae with reddish brown to pink column covered from margin to limbus with rows of endocoelic nonadhesive vesicles. Margin with endocoelic vesicles atop marginal projections; each projection bears a single holotrichous acrorhagus on its oral surface. Tentacles may be pink, orange, or purple, with an opaque white longitudinal stripe and white crossbars. Tentacles arranged in three or four cycles, approximately 
80 total. In the field, patterning of oral disk and tentacles and column morphology distinguish Bunodosoma californica from I. bespervolita; the morphology and cnidom of the margin and column distinguish preserved specimens. Column color and morphology distinguish live specimens of Bunodosoma californica and $A$. dowii; cnidom and column histology differentiate preserved specimens. Bunodosoma californica is distinguished from Bunodosoma grandis (Verrill, 1869) and Bunodosoma caissarum Corrêa in Belém, 1988, the two species of Bunodosoma reported from Central and South America, by the number of tentacles: members of Bunodosoma grandis and Bunodosoma caissarum have 120-500 tentacles (Verrill 1869, Carlgren 1952, Belém 1988).

COLUMN: Freshly collected specimens reddish brown to pink; vesicles same color as column. Live specimens approximately 20$30 \mathrm{~mm}$ wide at base, up to $40 \mathrm{~mm}$ tall; preserved specimens approximately $7-15 \mathrm{~mm}$ wide at base and $8-20 \mathrm{~mm}$ tall. Diameter of distal column exceeding that of proximal column, expanded individuals trumpet- or vaseshaped (Figure 4C). Fosse deep. Margin denticulate, with vesicle-covered marginal projections; each projection typically bears a single holotrichous acrorhagus on its oral surface. Vesicles of column rounded, endocoelic and exocoelic (Figures $3 A, 4 C, 7,8 B$ ); those of endocoels more prominent than those of exocoels. Vesicles in rows distally, linear arrangement not discernable proximally. Vesicles slightly larger and sometimes compound distally; maximum diameter less than 1.0 $\mathrm{mm}$ in preserved specimens. Adherent base roughly circular in outline, same color as distal column, with strong basilar muscles.

ORAL DISK AND TENTAClEs: Oral disk and tentacles same color as column; oral disk may be marked with opaque white or yellowish rays. Mouth atop oral cone, elongate along directive axis. Tentacles stout, with perforate tips, some with purple cast on oral surface, number from 48 to about 100 , in up to six cycles, shorter than oral disk diameter in expanded live specimens and approximately $5 \mathrm{~mm}$ long in an expanded preserved individual. Innermost tentacles same length as outermost tentacles. Each tentacle typically with opaque white cross-marks; tip of tentacle

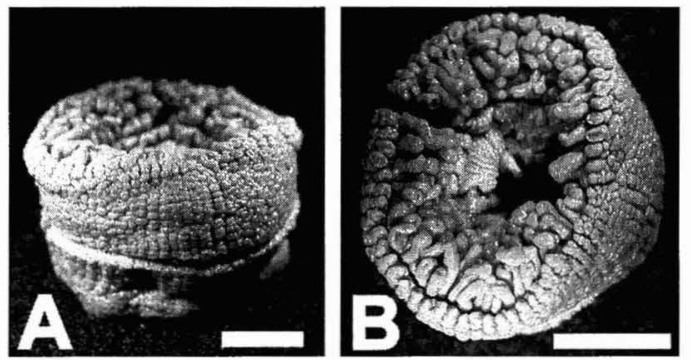

Figure 7. Lectotype of Bunodosoma californica Carlgren, 1951 (usnm 49447). Scale $=5 \mathrm{~mm}$. $A$. Side view of whole specimen reassembled from two halves. Note dense covering of rounded vesicles. $B$. Oral view. Note denticulate margin and short, blunt tentacles.

may be lighter than base. Tentacles of preserved specimens blunt, thick.

MESENTERIES AND INTERNAL ANATOMY: Number of siphonoglyphs variable because of regeneration; in animals with hexamerously arranged mesenteries, two siphonoglyphs each attached to directive mesenteries. Larger mesenteries with large oral and marginal stoma. Mesenteries in four or five cycles, up to about 100 , arranged hexamerously, same number distally and proximally. Mesenteries of first three or four cycles typically perfect; all perfect mesenteries fertile. Imperfect mesenteries sterile. Gonochoric. Mesenterial retractor muscles diffuse, bandlike (Figure $3 D$ ). Parietobasilar muscles weak, with small pennon and few lateral branches (Figure $3 D$ ). Marginal sphincter strong, circumscribed, palmate to pinnate (Figure $3 B, C$ ).

CNIDOM: Spirocysts, basitrichs, microbasic $b$-mastigophores, microbasic p-mastigophores, holotrichs (Figure 5D,H). Sizes and distribution of cnidae given in Table 3.

DISTRIBUTION AND NATURAL HISTORY: Pacific Ocean and Gulf of California, Mexico, to El Salvador. Ability to undergo fission unknown: although all specimens seen in the field solitary, several specimens bear scars indicative of regeneration, and the number of siphonoglyphs is variable.

TYPE MATERIAL: Lectotype: Collected by E. F. Ricketts, 26 March 1940, Gulf of California, [Mexico], [Baja California Sur], Puerto Escondido (USNM 49477). Paralectotypes: 
TABLE 3

Cnidae of Bunodosoma californica

\begin{tabular}{lllll}
\hline \hline Tissue & \multicolumn{1}{c}{ Cnida } & $\mathrm{N}$ & $n$ & \multicolumn{1}{c}{ Range $(\mu \mathrm{m})$} \\
\hline Tentacle & Spirocyst (E) & $4 / 4$ & 50 & $15.8-32.2(36.5)$ by $(1.6) 2.0-3.9(4.5)$ \\
& Large basitrich (G) & $4 / 4$ & 57 & $19.7-33.1$ by $(1.8) 2.4-4.1$ \\
Acrorhagi & Wide holotrich (A) & $4 / 4$ & 66 & $27.3-49.7$ by 3.0-5.6 \\
Distal margin & Small basitrich (H) & $4 / 4$ & 30 & $15.7-21.1$ by 1.8-3.1 (3.8) \\
& Large basitrich (G) & $4 / 4$ & 26 & $24.2-29.9$ by 2.6-4.1 \\
Column & Small basitrich (H) & $4 / 4$ & 46 & $14.8-18.6$ by 2.1-3.5 \\
& Large basitrich (G) & $4 / 4$ & 57 & $20.6-31.3$ by 2.3-4.1 \\
Actinopharynx & Small basitrich (H) & $4 / 4$ & 31 & $9.8-13.3$ by $1.7-3.0(3.4)$ \\
& Large basitrich (G) & $4 / 4$ & 73 & $19.4-32.9$ by 2.5-4.8 \\
Filament & Microbasic $p$-mastigophore I (L) & $2 / 4$ & 10 & $15.8-22.6$ by $4.4-5.4$ \\
& Small basitrich (B) & $3 / 4$ & 37 & $(10.4) 12.7-16.7$ by $1.6-2.4(2.7)$ \\
& Large basitrich (G) & $2 / 4$ & 12 & $23.1-29.9$ by 2.7-3.0 \\
& Large microbasic b-mastigophore (D) & $4 / 4$ & 39 & $27.2-34.8$ by 3.8-6.2 \\
& Microbasic $b$-mastigophore (K) & $4 / 4$ & 43 & $14.7-21.8$ by 2.9-4.5 (4.9) \\
& Microbasic $p$-mastigophore I (L) & $4 / 4$ & 42 & $17.1-22.9$ by 3.5-5.4
\end{tabular}

Note: $\mathrm{N}$ is the proportion of examined individuals having a particular type of cnidae; $n$ is the number of capsules measured. Values in parentheses are measurements from exceptionally small or large cnidae. In most specimens, the actinopharynx was everted; slide preparations from this tissue contained few cnidae. Letters refer to Figure 5.

Collected by E. F. Ricketts, 26 March 1940, Gulf of California, [Mexico], [Baja California Sur], Puerto Escondido (USNM 1013363, 1013364).

other material eXamined: Collected by M. Daly and L. Francis, 13 November 2001, intertidal, Pacific Ocean, Mexico, Baja California Sur, Los Cerritos (кunнм 1619); collected by G. Lindsay, April 1966, Gulf of California, Mexico (CAS 95945); collected by F. B. Steiner, 4 October 1974, intertidal, $\mathrm{Pa}-$ cific Ocean, El Salvador, Acajutla (cas 280).

TAXONOMIC REMARKs: The type series of Bunodosoma californica is heterogeneous: of the three syntypes, two belong to Bunodosoma californica and one belongs to Anthopleura dowii (Figures 7, 8). To unambiguously establish Bunodosoma californica as distinct from its pro parte synonym, $A$. dowii, I designate the larger, dissected specimen belonging to Bunodosoma californica (Figure 7) the lectotype of Bunodosoma californica Carlgren, 1951. The remaining specimens (Figure 8) are now paralectotypes. Because none of the syntypes was illustrated in the original description, there is no reason a priori to designate either of the specimens belonging to Bunodosoma californica as the lectotype (i.e., recommendation $74 \mathrm{~B}$, International Commission on
Zoological Nomenclature 1999); the larger specimen was chosen because it is dissected, and thus the generic and specific characters can be assessed without further destruction. The distal portion of this specimen is $25 \mathrm{~mm}$ wide and $8 \mathrm{~mm}$ tall; the proximal portion is $25 \mathrm{~mm}$ wide and $9 \mathrm{~mm}$ tall.

\section{ACKNOWLEDGMENTS}

Special thanks to L. Francis for her help in the field and to L. E. Calderon (Centro de
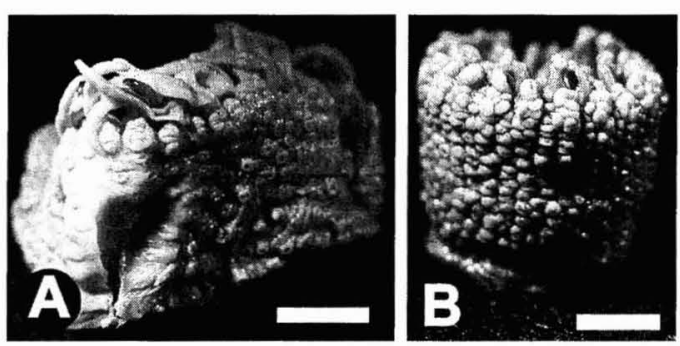

Figure 8. Paralectotypes of Bunodosoma californica Carlgren, 1951. Scale $=5 \mathrm{~mm}$. $A$. Specimen belonging to $A$. dowii (USNM 1013364). Note sparse, cup-shaped verrucae and conical tentacles. $B$. Specimen belonging to Bunodosoma californica (USNM 1013363). Note densely packed, rounded vesicles and short, blunt tentacles. 
Investigación Científica y de Educación Superior de Ensenada) for his assistance obtaining collecting permits. S. D. Cairns, J. B. Geller, A. Johnston, R. van Syoc, and E. Lazo-Wasem generously provided access to preserved material. Comments from D. G. Fautin and V. B. Pearse improved the manuscript.

\section{Literature Cited}

Andres, A. 1883. Le Attinie. Coi Tipi der Salviucci, Rome.

Belém, M. J. C. 1988. Anatomy and biology of Bunodosoma caissarum Corrêa, 1964 (Cnidaria, Anthozoa, Actiniidae). An. Acad. Bras. Cienc. 60:365-375.

Belém, M. J. C., and S. M. Pinto. 1990. Morphological and microanatomical study of Anthopleura krebsi Duchassaing \& Michelotti, 1860 (Cnidaria, Anthozoa, Actiniidae), a new record in Brazil. An. Acad. Bras. Cienc. 62:183-192.

Belém, M. J. C., A. Herrera, and E. Schlenz. 1996. On Isoaulactinia stelloides (McMurrich, 1889), n. gen., n. comb. (Cnidaria; Actiniaria; Actiniidae). Biociências 4:77-88.

Boveri, T. 1893. Das Genus Gyractis, eine radial-symmetrische Actinienform. Zool. Jahrb. Abt. Syst. 7:241-253.

Brandt, J. F. 1835. Prodromus descriptionis animalium ab H. Mertensio observatorum, Fasc. I. Sumptibus Academiae, Petrpolis.

Brusca, R. C. 1973. Common intertidal invertebrates of the Gulf of California. University of Arizona Press, Tucson.

Carlgren, O. 1921. Actiniaria I. Danish Ingolf Exped. 5 (9): 1-241.

- 1928. Actiniaria der Deutschen Tiefsee-Expedition. Deutschen TiefseeExped. 1898-1899 22:125-266.

. 1938. South African Actiniaria and Zoantharia. Kungl. Sven. Vetenskapsakad. Handl. (3rd series) 17:1-148.

- 1949. A survey of the Ptychodactiaria, Actiniaria and Corallimorpharia. Kungl. Sven. Vetenskapsakad. Handl. (4th series) $1: 1-121$.

. 1951. The actiniarian fauna of the Gulf of California. Proc. U.S. Natl. Mus. 101:415-449.
1952. Actiniaria from North America. Ark. Zool. (2nd series) 30:373-390.

Daly, M., and J. C. den Hartog. Taxonomy, circumscription, and usage in Antbopleura (Cnidaria: Anthozoa: Actiniaria) from the Gulf of Mexico and Caribbean. Bull. Mar. Sci. (in press).

Dana, J. D. 1846. Zoophytes. Vol. VII of the U.S. Exploring Expedition during the years $1838,1839,1840,1841,1842$. Lea and Blanchard, Philadelphia.

Duchassaing de Fonbressin, P., and G. Michelotti. 1860. Mémoir sur les corralliares des Antilles. Imprimerie Royale, Turin.

Dunn, D. F., F.-S. Chia, and R. Levine. 1980. Nomenclature of Aulactinia (=Bunodactis), with a description of Aulactinia incubans n. sp. (Coelenterata: Actiniaria), an internally brooding sea anemone from Puget Sound. Can. J. Zool. 58:2071-2080.

England, K. W. 1987. Actiniaria from the Red Sea and tropical Indo-Pacific. Bull. Br. Mus. Nat. Hist. 53:205-292.

Fischer, P. 1874. Recherches sur les Actinies des côtes océaniques de France. Nouv. Arch. Mus. Nat. Hist. Paris 10:193-244.

Francis, L. 1988. Cloning and aggression among sea anemones (Coelenterata: Actiniaria) of the rocky shore. Biol. Bull. (Woods Hole) 174:241-253.

Geller, J. B., and E. D. Walton. 2001. Breaking up and getting back together: Evolution of symbiosis and cloning in sea anemones (genus Anthopleura) inferred from a molecular phylogeny. Evolution 55:1781-1794.

Hand, C. 1955. The sea anemones of central California, part II. Wasmann J. Biol. 13:37-99.

den Hartog, J. C. 1987. A redescription of the sea anemone Bunodosoma biscayensis (Fischer 1874) (Actiniaria, Actiniidae). Zool. Meded. (Leiden) 61:533-559.

International Commission on Zoological Nomenclature. 1999. International code of zoological nomenclature. International Trust for Zoological Nomenclature, London.

Jandel Scientific Software. 1995. Sigma ScanPro, version 2.0. Jandel Corporation (http://www.spss.com/sigmascan). 
Kerstitch, A. 1989. Sea of Cortez marine invertebrates. Sea Challengers, Monterey, California.

Mariscal, R. N. 1974. Nematocysts. Pages 129-166 in L. Muscatine and H. M. Lenhoff, eds. Coelenterate biology: Reviews and new perspectives. Academic Press, New York.

McCommas, S. A. 1983. A taxonomic approach to the evaluation of the charged state model using twelve species of sea anemone. Genetics 103:741-752.

1991. Relationships within the family Actiniidae (Cnidaria, Actiniaria) based on molecular characters. Hydrobiologia 216/ 217:509-512.

McMurrich, J. P. 1889. The Actiniaria of the Bahama Islands, W.I. J. Morphol. 3:180.

Presnell, J. K., and M. P. Schreibman. 1997. Humason's animal tissue techniques. Johns Hopkins University Press, Baltimore.

Riemann-Zürneck, K., and V. A. Gallardo.
1990. A new species of sea anemone (Saccactis coliumensis n. sp.) living under hypoxic conditions on the central Chilean shelf. Helgol. Meeresunters. 44:445-457.

Steinbeck, J. 1951. The log from The Sea of Cortez. Viking Press, New York.

Stephenson, T. A. 1918. Coelenterata. Part I. Actiniaria. Nat. Hist. Rep. Br. Antarct. Exped. 5:1-68.

1928. The British sea anemones. Vol. 1. The Ray Society, London.

Verrill, A. E. 1864. List of the polyps and corals sent by the Museum of Comparative Zoology to other institutions in exchange, with annotations. Bull. Mus. Comp. Zool. $1: 29-60$.

1869. Review of the polyps of the west coast of America. Trans. Conn. Acad. Arts Sci. 1:377-567.

1899. Descriptions of imperfectly known and new actinians, with critical notes on other species, II. Am. J. Sci. 7:4150 . 